\title{
Calcium Hydroxide Washing Treatment of Jordanian Phosphogypsum for Utilization as Raw Material in Cement Industry
}

\author{
Ali F. Al-Shawabkeh ${ }^{1}$, Ziad S. H. Abu-Hamatteh²*, Walaa H. Saadeh ${ }^{3}$, Waid S. Omar ${ }^{3}$ \\ ${ }^{1}$ Physics and Basic Science Department, Faculty of Engineering Technology, Al-Balqa Applied University, Amman 11134, \\ Jordan \\ ${ }^{2}$ Civil Engineering Department, Faculty of Engineering Technology, Al-Balqa Applied University, Amman 11134, Jordan \\ ${ }^{3}$ Chemical Engineering Department, Faculty of Engineering Technology, Al-Balqa Applied University, Amman 11134, Jordan
}

Corresponding Author Email: hamatteh@bau.edu.jo

https://doi.org/10.18280/eesrj.060405

Received: 4 October 2019

Accepted: 1 December 2019

\section{Keywords:}

hydrate calcium sulfate, radioactivity, uranium, hydration, phosphogypsum, impurities, Jordan

\begin{abstract}
The main objective of this study is to control the hydration reaction rate of cement during its production process as phosphogypsum could be used as a substitute to natural gypsum in cement industry. However, the phosphogypsum impurities are pushing towards developing an efficient way to clean it due to their negative effect in hindering its use as an additive to the cement industry. The aim of this article is to treat phosphogypsum to be used in cement industry. To fulfil the purpose, samples from the Jordanian phosphogypsum were treated by washing with calcium hydroxide solution and then analyzed using X-ray Fluorescence Spectrometer. The analyses result of the treated samples indicated that the $\mathrm{P}_{2} \mathrm{O}_{5}$ percentage was reduced by around $16 \%$ after three times washing, whereas $100 \%$ removal of $\mathrm{U}$ was achieved. The reduction of $\mathrm{SiO}_{2}$ and $\mathrm{Al}_{2} \mathrm{O}_{3}$ were $42 \%$ and $20 \%$, respectively. Ti content was reduced by $20 \%$. According to the analyses, the radiation from phosphogypsum was negligible. Therefore, the treated Jordanian phosphogypsum can be used in cement industry. This will contribute to the reduction of waste phosphogypsum which considered as environmental concern from one side and provide cement industry with low cost raw material on the other side.
\end{abstract}

\section{INTRODUCTION}

Jordan is considered as one of the world's top countries which produce phosphate rock [1]. Phosphates resources are mainly used in fertilizers industry which has a great contribution in the Jordanian economic branch [2]. In Jordan phosphogypsum is a by-product of phosphate industry, where more than 40 million tons of phosphogypsum produced at a rate of three million tons per year from Aqaba and Eshidiya fertilizers plants. Figure 1 shows the Jordanian phosphate location map and the Jordan Phosphate Mines Company (JPMCs) [3]. The method of disposal used in Jordan is stacking in Aqaba [4]. The Jordanian phosphogypsum contains about $30 \%$ sulfur which is considered very large amount [5].

Hydrate calcium sulfate (phosphogypsum, $\mathrm{CaSO}_{4} \cdot 2 \mathrm{H}_{2} \mathrm{O}$ ) is produced as result of the phosphoric acid production when sulfuric acid is added to limestone. Phosphogypsum is a type of gypsum consists of calcium sulfate $\left(\mathrm{CaSO}_{4}\right)$ as a major component with small quantities of silica usually as quartz, and unreacted phosphate rock. Uranium and radium, in addition to minor amounts of toxic metals, namely, barium, arsenic, chromium, cadmium, mercury, lead, silver and selenium and fluoride and aluminum are also found in phosphogypsum and its pore water [6]. In addition, it contains impurities of phosphoric acid $\left(\mathrm{P}_{2} \mathrm{O}_{5}\right)$ and fluorine compounds (F-) which poses a serious challenge for the phosphogypsum recycling process [7]. Generally, the composition of phosphogypsum varies due to the source of the phosphate rock (phosphorite) and the reactor conditions. Basically, phosphate rock contains $18-40 \% \mathrm{P}_{2} \mathrm{O}_{5}$, in addition to some uranium amounts ranges between 70-200 ppm and sometimes up to 800 ppm [8].

Phosphogypsum is a grey moist by-product formed during the phosphoric acid production by the wet process (ammonium phosphate fertilizer). In Jordan, phosphoric acid production rate can be estimated to be around 500 thousand metric ton annually [1]. Phosphogypsum is commonly produced when the phosphate ore (apatite) reacts with concentrated sulphuric.

Generally, to produce one ton of phosphoric acid there is five tons of phosphogypsum produced $[9,10]$. In Jordan, the production ratio is approximately 5.0-5.3 ton of phosphogypsum/ ton of marketable $\mathrm{P}_{2} \mathrm{O}_{5}$ produced. This amount varies due to the composition of the phosphate rock and this huge amount of phosphogypsum is stacked in Aqaba every year (Jordanian Phosphate Mines Company (JPMC) [11]. Phosphogypsum is considered as an asset rather than as a waste, but its content of impurities hinders its use efficiently. The $\mathrm{P}_{2} \mathrm{O}_{5}$ impurities are harmfully affect the hydration of cement at its early stages [12].

Particle size of phosphogypsum is below $200 \mu \mathrm{m}$. It has low strength and adhesive properties, and it has crystals with regular shape rhombic and hexagonal $[13,14]$. On the other hand, natural gypsum has fewer regular crystals shape, this means that phosphogypsum has more complex structure than natural gypsum (Figure 2).

However, phosphogypsum and natural gypsum have similar chemical compositions [15], therefore; the addition of 
phosphogypsum to cement instead of natural gypsum in the last stage of cement industries is expected to have the same chemical effect either when it is added partially or totally.

Turkey was one of the most successful experiments in achieving mixing the phosphogypsum with natural gypsum in deferent percentages in order to produce the additional gypsum [16]. Therefore, in 1995 the management Balikesir cement plant decided, to increase the phosphogypsum proportion which was added to cement to $50 \%$ in the mixture of phosphogypsum-natural gypsum [17].

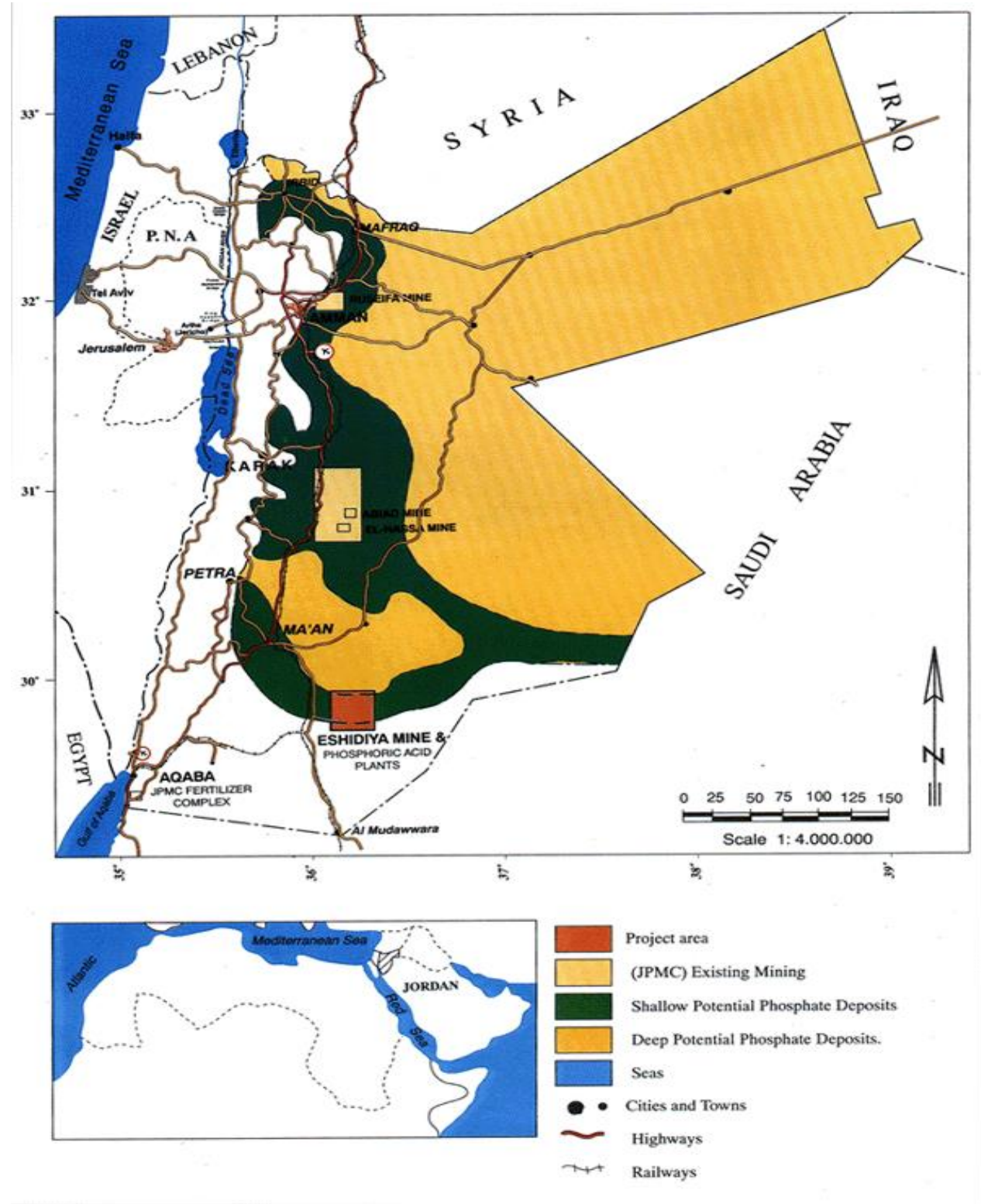

Figure 1. Jordanian phosphate location map and JPMCs

Moreover, there are many studies conducted that adding 5$10 \%$ phosphogypsum in cement clinker worked well in terms of its compressive strength and its other basic engineering properties due to the unique properties of dihydrate phosphogypsum under compaction-consolidation [18-21]. Another study for using $0-30 \%$ cement replacement by phosphogypsum also gave maximum flexural strength with $10 \%$ phosphogypsum [22].

In Jordan, there is a big expansion in cement production which essentially requires an increasing demand for using gypsum additive. There are at least five factories in Middle and Northern parts of Jordan. Some of these factories especially that are located near Aqaba and Alshidya which represent the main points for Phosphogypsum stacks. Once the impurities in the phosphogypsum are reduced to an acceptable limit, then it will be ready for useful uses in the cement industry.

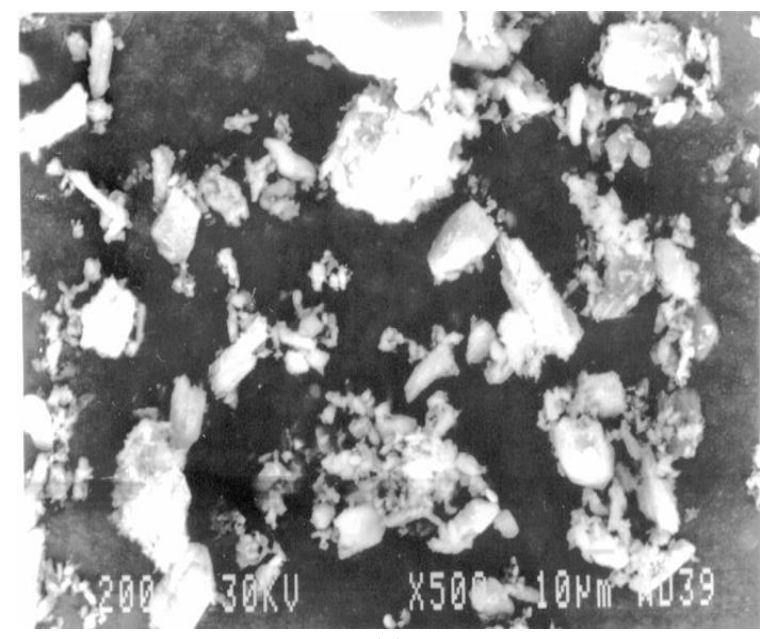

(a) 


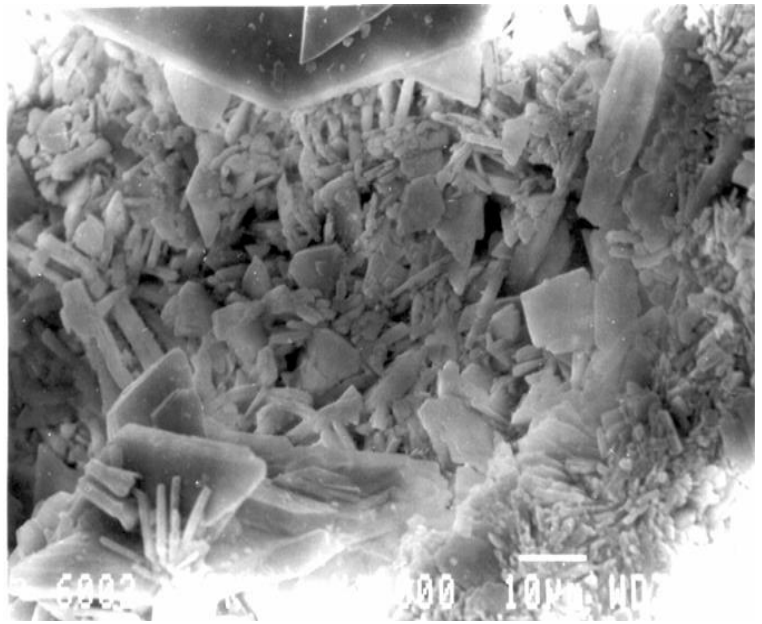

(b)

Figure 2. (a) SEM micrograph of crystalline structure of natural gypsum $(\times 500)$; (b) SEM micrograph of crystalline structure of phosphogypsum (x1000) [23]

Furthermore, phosphogypsum can be widely used in road construction, agriculture as supplementary fertilizer, manufacturing of insecticides and fungicides, aggregate in Portland cement concrete, insulation material in houses and other buildings, landfills, Plastic industry, Sugar industry, paper industry, fire suppression, remove toxic elements from the soil, animals feed, production of roof tiles [19, 24]. Moreover, phosphogypsum reduce greenhouse gas emission and odor emission during production of compost from food waste and animal waste. The composition of phosphogypsum after drying comprises of Gypsum $(94.9 \%), \mathrm{H}_{2} \mathrm{O}(0.2 \%), \mathrm{SiO}_{2}$ (3.59\%), $\mathrm{P}_{2} \mathrm{O}_{5}(1.4 \%)$ and $\mathrm{F}-(10 \mathrm{ppm})$.

\subsection{Radioactivity of phosphogypsum}

The very large amounts production of phosphogypsum for many years is considered one of the critical parameters in causing chemical and radiological environmental effects [19, 25]. The annual world production of Phosphogypsum is more than 250 million ton, $15 \%$ of this amount are used as aggregate in cement industry and as setting moderator in gypsum and cement industry, $85 \%$ of it are considered mineral waste and stacked in piles due to its radioactivity and other environmental problems caused by its content of heavy metals $[1,7]$.

In some countries, there are laws govern the usage of phosphogypsum because it contains many radioactive elements such as cadmium $(\mathrm{Cd})$, radon (Ra-222), radium (Ra226), uranium (U), polonium (Po) and thorium (Th). But radon-222 is volatile and has short half-life so it doesn't form a very serious problem. Environmental protection agency (EPA) permits the using of phosphogypsum if its content of radium-226 is below ten picocuries per gram $(10 \mathrm{pCi} / \mathrm{g})$ (Table 1). This amount equivalent to $0.01 \mathrm{ppm}$ or the equivalent of less than one drop of water into Olympic size swimming pool [26].

Phosphogypsum possess harmful components such as fluoride compounds, heavy metals such as lead and cadmium and residual acidity such as phosphoric acid (Table 2).

The disposal of phosphogypsum which is produced in bulk quantity in the form of landfill will need huge land area. Hence, getting use of phosphogypsum in building materials will lead to dispose it as chemical and radioactive waste and will also reduce the cost of cement production $[19,27]$.

Table 1. The content of radioactive isotopes in gypsum (pCi/g) [28]

\begin{tabular}{cccccc}
\hline & ${ }^{238} \mathbf{U}$ & ${ }^{226} \mathbf{R a}$ & ${ }^{232} \mathbf{T h}$ & ${ }^{40} \mathbf{K}$ & $\begin{array}{c}\text { Radium } \\
\text { equivalence }\end{array}$ \\
\hline $\begin{array}{c}\text { Natural } \\
\text { gypsum }\end{array}$ & 0.4 & 0.6 & 0.2 & 2 & 1 \\
$\begin{array}{c}\text { Phosphogy } \\
\text { psum } \\
\text { (maritime) }\end{array}$ & 4 & 22 & 0.5 & 6 & 23 \\
$\begin{array}{c}\text { Phosphogy } \\
\text { psum } \\
\text { (magmati) }\end{array}$ & $<1$ & 3.2 & 0.6 & 7 & 5 \\
$\begin{array}{c}\text { Phosphate } \\
\text { rock } \\
\text { (maritime) }\end{array}$ & 40 & 38 & 1.2 & 6 & 40 \\
$\begin{array}{c}\text { Phosphate } \\
\text { rock } \\
\text { (magmati) }\end{array}$ & 2 & $1-2$ & 3 & 10 & 8 \\
\hline
\end{tabular}

Table 2. Heavy metals content of phosphogypsum in (ppm) [4]

\begin{tabular}{ccc}
\hline Metal & $\begin{array}{c}\text { Maritime } \\
\text { phosphogypsum }\end{array}$ & $\begin{array}{c}\text { Magmatic } \\
\text { phosphogypsum }\end{array}$ \\
\hline $\mathrm{Cd}$ & 8 & $<1$ \\
$\mathrm{Zn}$ & 15 & 1 \\
$\mathrm{Cu}$ & 6 & 4 \\
$\mathrm{~Pb}$ & 4 & 6 \\
$\mathrm{As}$ & 5 & 3 \\
$\mathrm{Ni}$ & 9 & $<1$ \\
$\mathrm{Hg}$ & 0.1 & - \\
\hline
\end{tabular}

\subsection{Phosphogypsum processing}

Generally, there are two recovery methods of sulfur from phosphogypsum, i.e., either by using sulfate-reducing bacteria or the thermal and chemical analysis [29, 30]. In this study the phosphogypsum can be converted into sulfur using the second method by conversion of calcium sulfide to sulfur by applying the method of Rosenwald, Hamblin, Urban, and Zimmerman for oxidation the ammonium bi-sulfide to sulfur [31, 32].

\subsection{Phosphogypsum in Cement Industry}

To prepare phosphogypsum for using in cement production, gypsum is added in clinker to regulate or increase the setting time of cement; when phosphogypsum used instead of normal gypsum it obviously prolonged the hardening time compared to what usually needed with natural gypsum due to the presence of phosphate [33, 34]. Furthermore, this addition reduces the clinkerization temperature under the same conditions which used with normal gypsum [35]. Several studies mentioned that the soluble $\mathrm{P}_{2} \mathrm{O}_{5}$ and $\mathrm{F}$ impurities led to increase setting time and decrease compressive strength as well as the density [7, 36-38].

The phosphoric acid content $\left(\mathrm{P}_{2} \mathrm{O}_{5}\right)$ in phosphogypsum is essentially required to be removed in order to eliminate its negative impact. Basically, most of the soluble impurities in phosphogypsum could be partially extracted by washing with water [34, 39], but this will lead to secondary pollution and extra cost.

Nevertheless, there is another problem in using 
phosphogypsum in cement industry as it, its content of radioactive elements such as uranium due to its effect on human health. This problem can be efficiently reduced by washing because the radiation of Jordanian phosphogypsum is very low.

The objective of this study is to investigate the process of treating phosphogypsum to make it useful for cement industry. The removal of impurities by washing phosphogypsum with limestone in aqueous medium (Calcium Hydroxide) and the conversion of soluble $\left(\mathrm{P}_{2} \mathrm{O}_{5}\right)$ in water to insoluble phosphate (calcium phosphate) in water at ambient temperature is studied experimentally.

\section{MATERIALS AND METHODS}

Phosphogypsum samples were obtained from the Jordan Phosphate Mines Company in Amman-Jordan. Experimental investigations were carried out to study the removal or reduction of $\mathrm{P}_{2} \mathrm{O}_{5}$ from phosphogypsum by washing with calcium hydroxide solutions. Ten samples of fresh phosphogypsum $(100 \mathrm{~g})$ were taken for the analysis. The treatment solution was prepared by dissolving $4 \mathrm{~g}$ of calcium hydroxide (commercial grade lime stone) in suitable amount of tab water. The phosphogypsum was added to the solution and mixed vigorously for 30 minutes. The phosphogypsum was then separated by filtration and dried in an oven under 100-105 ${ }^{\circ} \mathrm{C}$ for 10 hours. Samples of the filtrated phosphogypsum were prepared (fuse or compress) to be analyzed using X-Ray Fluorescence (XRF) spectroscopy.

The effect of washing more than one time (3 times) was investigated by following the same experiments on the treated samples. In all samples the percentages of different constituents were measured before and after washing with calcium hydroxide for both washing one time and three times, then the average and the standard deviation of the ten readings for each constituent were calculated and plotted.

To determine the amount of radioactivity in phosphogypsum, the radiation detector (multi detector) can be used to measure the radiation in raw phosphogypsum and in the treated phosphogypsum.

X-Ray Fluorescence (XRF) spectrometry (ARL8480S SEQ/SIM XRF) was used during the current study to analyze samples and determine its chemical construction especially sulfur and phosphoric acid content, through preparing fused samples at 1100 , and using compression techniques in the hydraulic press after drying and milling it as powder.

\section{RESULTS AND DISCUSSION}

The efficiency of treating raw samples of Jordanian phosphogypsum by washing with calcium hydroxide was evaluated experimentally by analyzing ten samples before and after washing. The results shown in Figure 3 indicated that $\mathrm{P}_{2} \mathrm{O}_{5}$ percentage was reduced after washing by around $5 \%$ and after washing three times the reduction percentage interestingly increased to approximately $16 \%$. In this case, this water-soluble impurity in phosphogypsum was converted into an insoluble matter as required. This is because $\mathrm{P}_{2} \mathrm{O}_{5}$ can react with $2 \mathrm{CaO}, \mathrm{SiO}_{2}$ of the cement clinker and forms a solid solution as a result [40]. Therefore, $\mathrm{P}_{2} \mathrm{O}_{5}$ has a direct effect on the constitution and hardening of Portland cement. However, the reduction percentage can be affected by different parameters such as phosphogypsum particle size, acid concentration, the mass of phosphogypsum to the mass of solution figure in addition to the number of washings [41]. Moreover, as the $\mathrm{P}_{2} \mathrm{O}_{5}$ increases the strength decreases until, when the $\mathrm{P}_{2} \mathrm{O}_{5}$ reaches $2.25 \%$ of the cement clinker, the cement fails to meet British Standard requirements [40]. It was reported that the increase in water cement ratio cement markedly affects the cement with high $\mathrm{P}_{2} \mathrm{O}_{5}$ percent more than the normal cement. The most remarkable result to emerge from the data is the total $100 \%$ removal of $U$ as shown in Figure 4. These results are of great interest on the side of recovery of the valuable uranium from waste phosphogypsum using by leaching in low cost calcium hydroxide solution obtained from commercial grade lime stone. The complete removal of uranium facilitates the application of phosphogypsum as a raw material for clinker production.

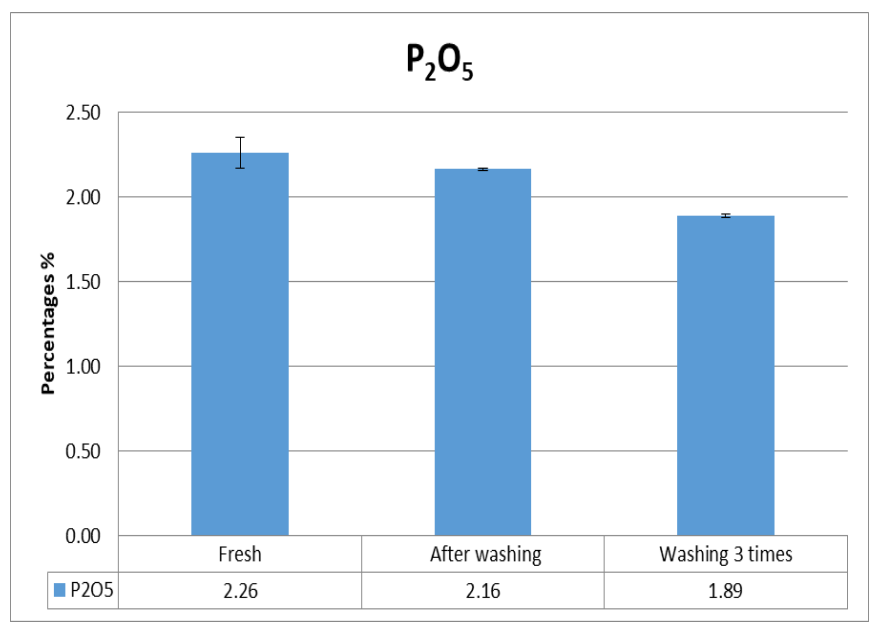

Figure 3. The reduction of $\mathrm{P} 2 \mathrm{O} 5$ concentration in phosphogypsum after washing with calcium hydroxide

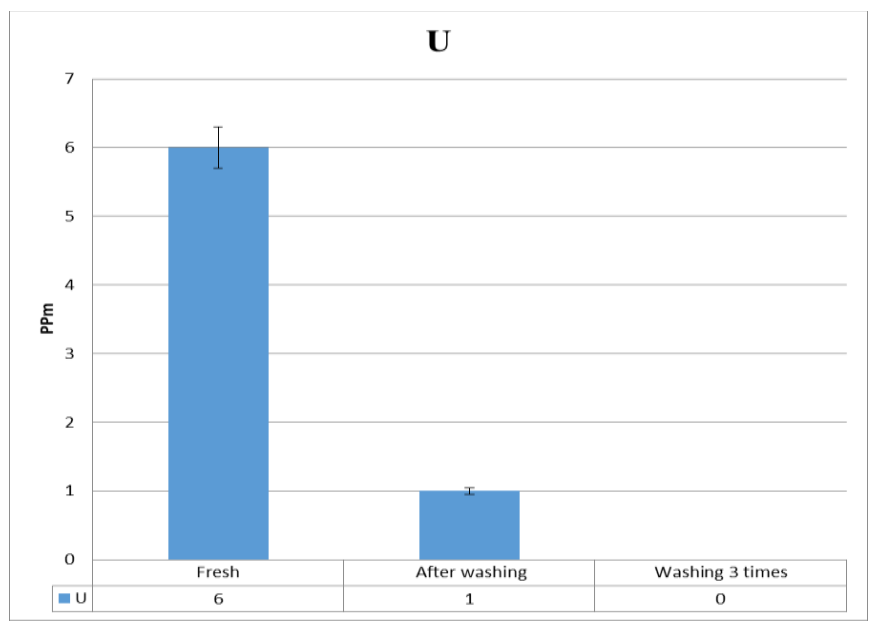

Figure 4. The potential of washing the Jordanian phosphogypsum with calcium hydroxide for the reduction of $\mathrm{U}$ concentration

The influence of washing of chemical analysis of $\mathrm{CaO}$ and $\mathrm{SiO}_{2}$ after washing with calcium hydroxide solutions are presented in Figures 5, 6, respectively. The treated samples showed a remarkable increase of $7 \%$ in the amount of $\mathrm{CaO}$ after washing (see Figure 5). The reduction percentage of $\mathrm{SiO}_{2}$ was around $36 \%$ based on the washing for one time, and after washing three times the percentage increased to $42 \%$. This can be attributed to the addition of limestone in the washing 
process. The measured amounts of calcium oxide and silicon oxide don't interfere with the required clinker properties as they are main raw materials for cement production.

\section{$\mathrm{CaO}$}

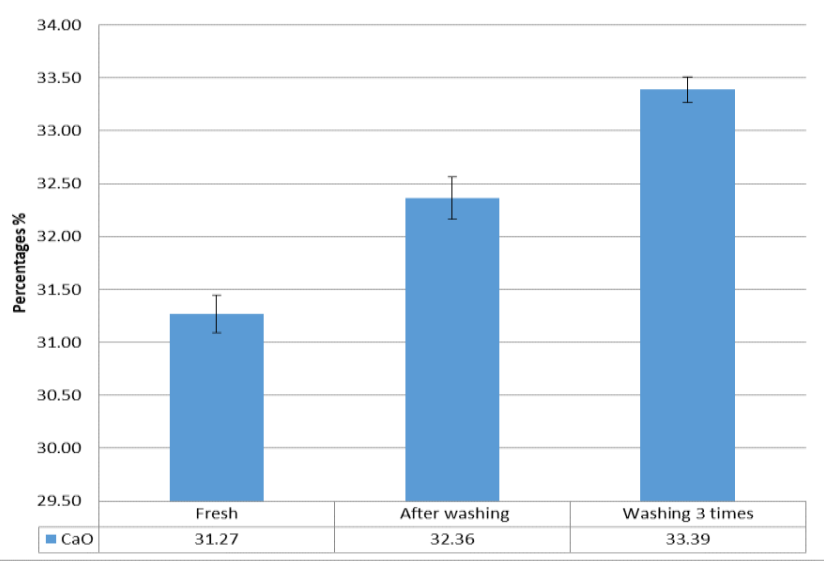

Figure 5. The reduction of of $\mathrm{CaO}$ concentration in phosphogypsum after washing with calcium hydroxide

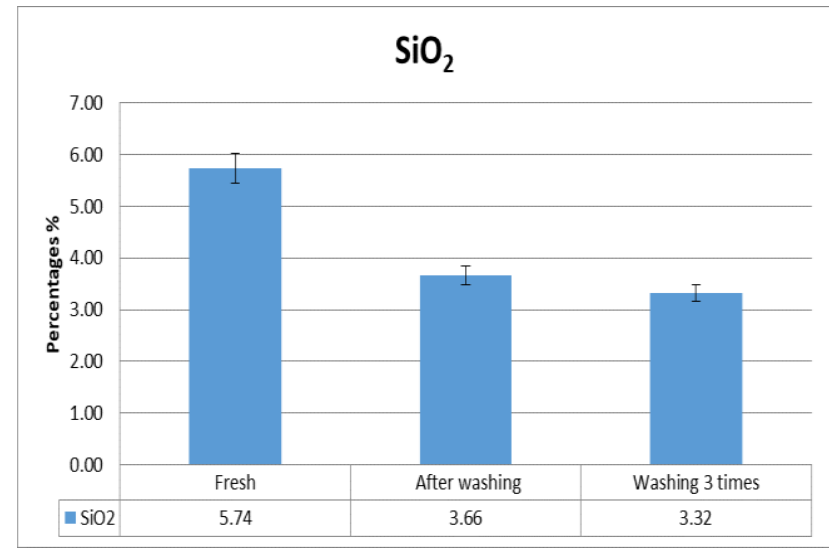

Figure 6. The potential of washing the phosphogypsum with calcium hydroxide for the reduction of $\mathrm{SiO}_{2}$ concentration

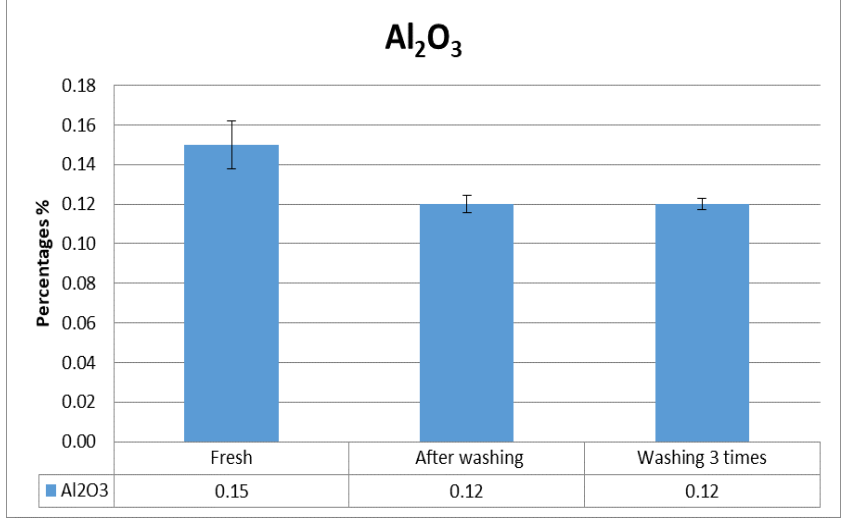

Figure 7. The reduction of $\mathrm{Al}_{2} \mathrm{O}_{3}$ concentration in phosphogypsum after washing with calcium hydroxide

Figures 7, 8 and 9 display the measured changed in the amount of $\mathrm{Al}_{2} \mathrm{O}_{3}, \mathrm{Fe}_{2} \mathrm{O}_{3}, \mathrm{MgO}$ and $\mathrm{SO}_{3}$ ratios, respectively. It can be envisaged that $\mathrm{Al}_{2} \mathrm{O}_{3}, \mathrm{Fe}_{2} \mathrm{O}_{3}$ and $\mathrm{MgO}$ were all reduced by around $20 \%$ after washing one time. But the analysis did not reveal any significant differences in the percentages of all of them after washing several times. The analysis shows that the presence of $\mathrm{Al}_{2} \mathrm{O}_{3}, \mathrm{Fe}_{2} \mathrm{O}_{3}$ and $\mathrm{MgO}$ in the treated phosphogypsum is at very small traces concentration and will not have any significance influence on the structure of the Portland cement. On the other hand, these components already present in the raw materials for cement manufacturing.

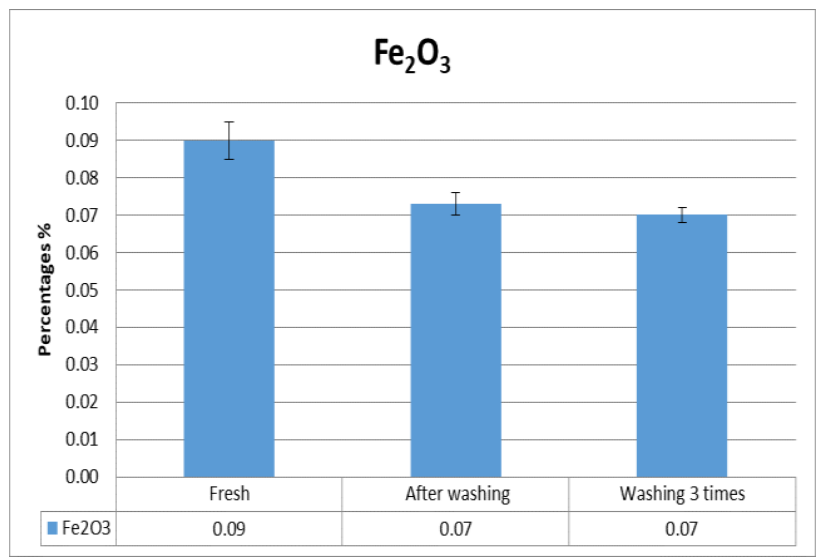

Figure 8. The potential of washing the phosphogypsum with calcium hydroxide for the reduction of $\mathrm{Fe}_{2} \mathrm{O}_{3}$ concentration

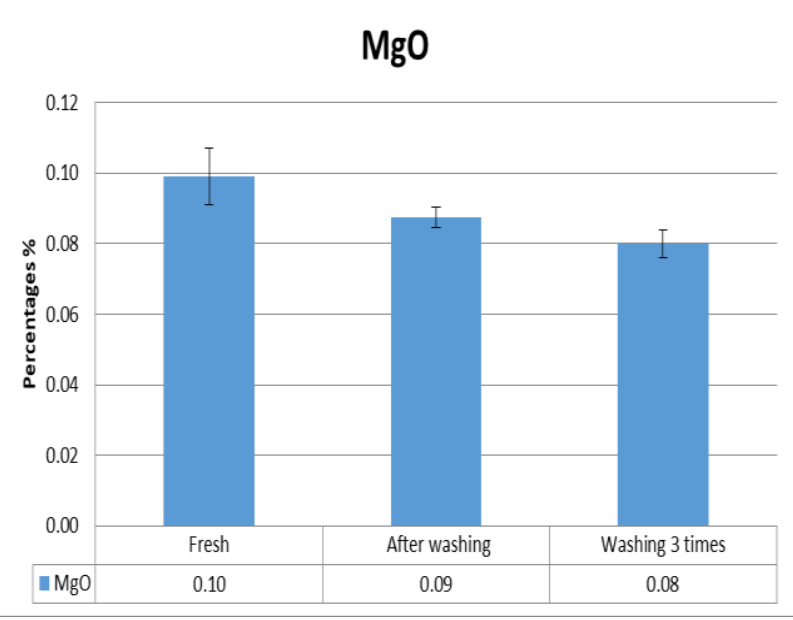

Figure 9. The reduction of $\mathrm{MgO}$ concentration in phosphogypsum after washing with calcium hydroxide

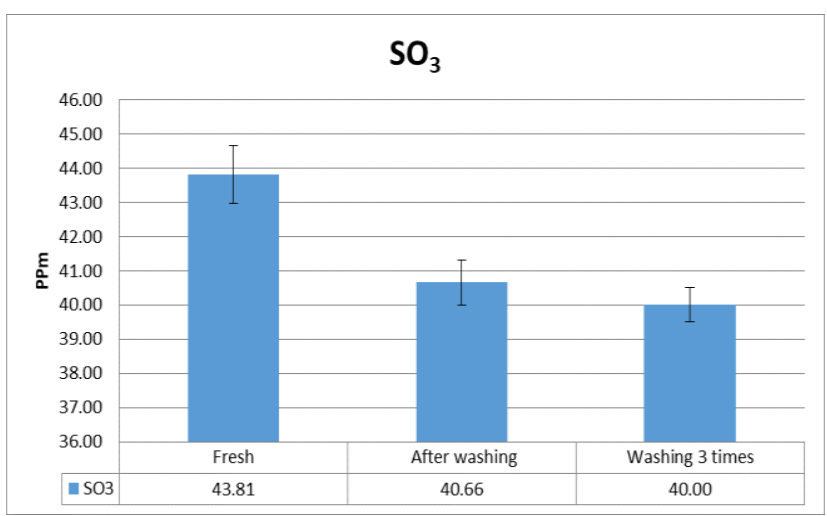

Figure 10. The reduction of $\mathrm{SO}_{3}$ concentration in phosphogypsum after washing with calcium hydroxide

The presence of $\mathrm{SO}_{3}, \mathrm{Sr}, \mathrm{Ti}$ and $\mathrm{Ni}$ in the treated phosphogypsum is presented in figures 10, 11, 12 and 13 respectively. The percentage of $\mathrm{SO}_{3}$ was reduced by $7 \%$ for washing one time and $9 \%$ after washing three times based on 
its measured values (Figure 10). Moreover, Sr was also reduced by around $4 \%$ after first washing, and 5\% after washing three times as demonstrated in Figure 11.

In a Similar scenario, Ti was reduced by around $18 \%$ after washing for one time and $20 \%$ after washing three times as shown in Figure 12. Finally, no significant differences in the reduction percentage of Ni. It is clearly shown that $\mathrm{SO}_{3}, \mathrm{Sr}, \mathrm{Ti}$ and $\mathrm{Ni}$ present in trace amounts before and after treatment.

\section{Sr}

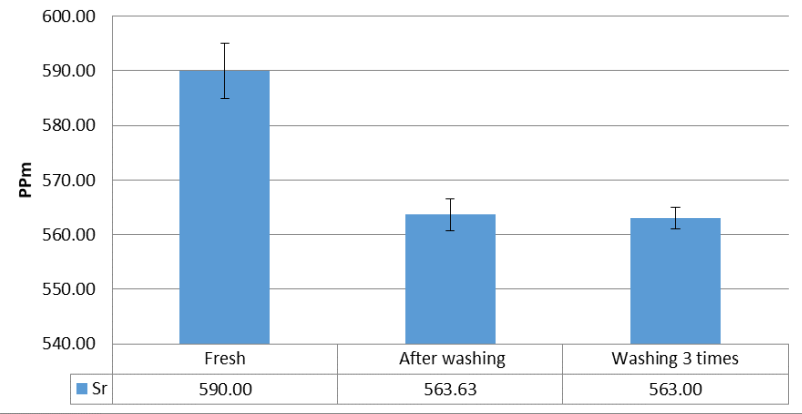

Figure 11. The potential of washing the phosphogypsum with calcium hydroxide for the reduction of $\mathrm{Sr}$ concentration

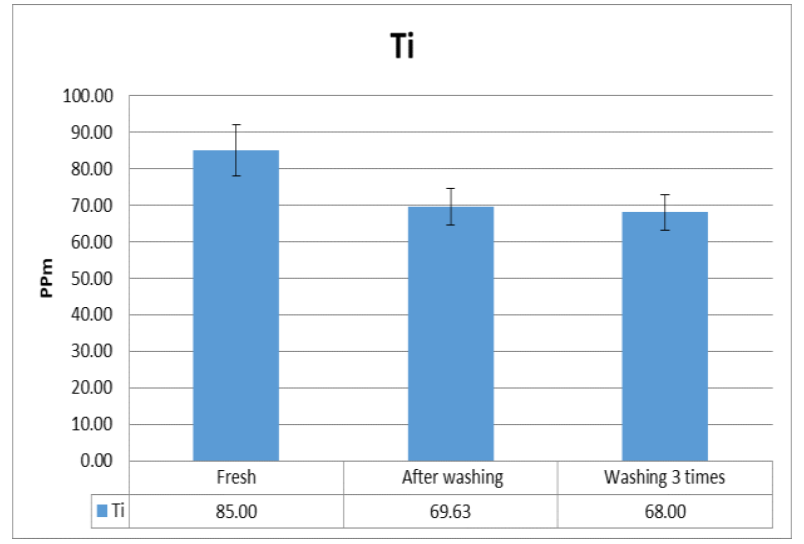

Figure 12. The reduction of Ti concentration in phosphogypsum after washing with calcium hydroxide

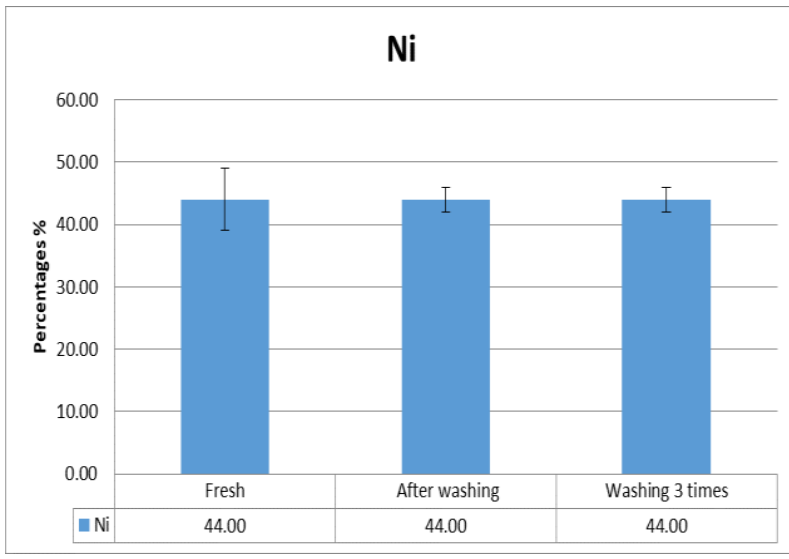

Figure 13. The potential of washing the phosphogypsum with calcium hydroxide for the reduction of $\mathrm{Ni}$ concentration

The potential for applying washing (leaching) process for modifying phosphogypsum as raw material in cement production is summarized in Figure 14. It is clearly that some components were reduced after washing in significant percentages. Thus, all the impurities were converted into inactive compounds in these samples especially $\mathrm{U}, \mathrm{SiO}_{2}$ and $\mathrm{P}_{2} \mathrm{O}_{5}$. Further treating the impurities in phosphogypsum will increase the process operation cost, but the obtained reduction percentages for the impurities will lead to reduce the cost as well. Moreover, in terms of radiation the measured value in raw phosphogypsum and treated phosphogypsum was measured as 0.11 and $0.1 \mu \mathrm{Sev} \quad(\mathrm{Sev}=1 \mathrm{~J} / \mathrm{kg}=100 \mathrm{Rad})$ respectively.

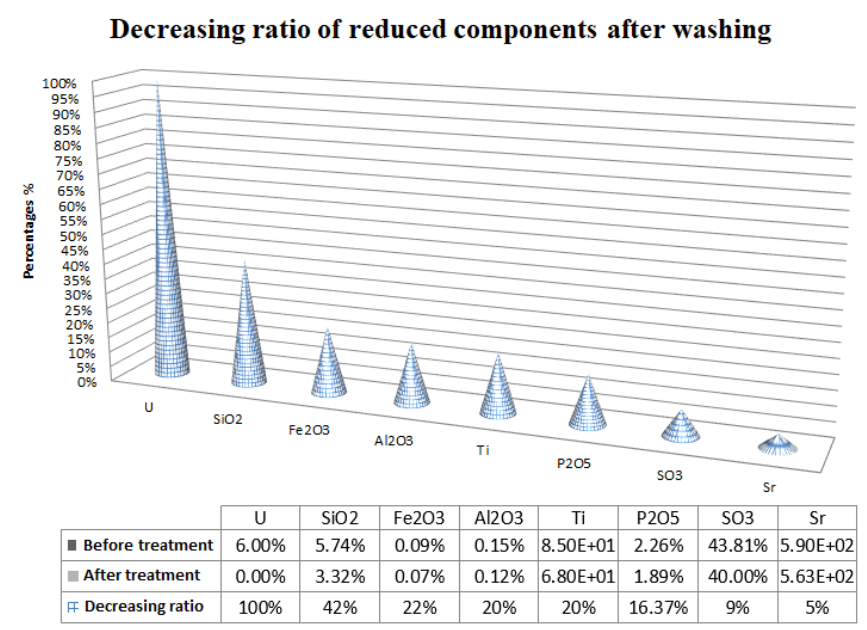

Figure 14. Decreasing ratio of reduced components after washing

\section{CONCLUSIONS}

The results obtained indicated that the Jordanian phosphogypsum can be treated and prepared to be used in cement industry instead of natural gypsum by low cost washing with calcium hydroxide. This will contribute in reducing the cost of cement production and reducing the environmental impacts of phosphoric acid production industry. Phosphoric acid can be reduced $16 \%$ by washing phosphogypsum with calcium hydroxide. It also can be reduced to much lower value by washing more than three times. In similar way, other constituents such as $\left(\mathrm{SiO}_{2}, \mathrm{Al}_{2} \mathrm{O}_{3}\right.$, $\mathrm{Fe}_{2} \mathrm{O}_{3}, \mathrm{SO}_{3}, \mathrm{Sr}, \mathrm{Ti}$ ) can be reduced significantly by washing with calcium hydroxide. Interestingly, after washing uranium, its percentage decreased from $6 \mathrm{ppm}$ to nil. In addition, the radiation in raw phosphogypsum and treated phosphogypsum is very low. A more detailed research and development work might help to ensure better use of treated phosphogypsum in construction industry or the feasibility of recovering large amounts of the sulfur from the treated phosphogypsum.

\section{ACKNOWLEDGMENT}

The authors acknowledge the support of the Jordan Phosphate Mines Company (JPMC) in Amman-Jordan by providing the experimental analysis and the materials.

\section{REFERENCES}

[1] Aliedeh, M.A., Jarrah, N.A. (2012). Application of full factorial design to optimize phosphogypsum beneficiation process $\left(\mathrm{P}_{2} \mathrm{O}_{5}\right)$ Reduction by using sulfuric 
and nitric acid solutions, Sixth Jordanian International Chemical Engineering Conference, Amman, Jordan.

[2] Aliedeh, M.A. (2018). Facorial design study of $\mathrm{P}_{2} \mathrm{O}_{5}$ reduction for Jordanian phosphogypsum using sulfuric and nitric acids solutions. Journal of Chemical Technology and Metallurgy, 53(3): 437-450.

[3] Abu-Hamatteh, Z.S.H. (2007). Geology, geochemistry and are characteristics of the Jordanian phosphates. Central European Geology, 50: 283-295. http://dx.doi.org/10.1556/CEuGeol.50.2007.3.6

[4] Al-Hwaiti, M. (2005). Heavy metal assessment of phosphogypsum waste stockpile material from Jordan. Journal American Society of Mining and Reclamation, 1: 1-22. http://dx.doi.org/10.21000/JASMR05010001

[5] Al-Hwaiti, M.S., Zielinski, R.A., Bundham, J.R., Ranville, J.F., Ross, P.E. (2010). Distribution and mode of occurrence of radionuclides in phosphogypsum derived from Aqaba and Eshidiya fertilizer industry, South Jordan. Chinese Journal of Geochemistry, 29: 261269. http://dx.doi.org/10.1007/s11631-010-0455-5

[6] Szynkowska, M.I., Pawlaczyk, A., Rogowski, J. (2011). Characterization of particles transmitted by wind from waste dump of phosphatic fertilizers plant deposited on biological sample surfaces. Air Quality Monitoring, Assessment and Management, 93-107. http://dx.doi.org/10.5772/16478

[7] Huang, Y., Qian, J., Kang, X., Yu, J., Fan, Y., Dang, Y., Zhang, W., Wang, S. (2019). Belite-calcium sulfoaluminate cement prepared with phosphogypsum: Influence of $\mathrm{P}_{2} \mathrm{O}_{5}$ and $\mathrm{F}$ on the clinker formation and cement performances. Construction and Building Materials, 203: 432-442. http://dx.doi.org/10.1016/j.conbuildmat.2019.01.112

[8] Hore-Lacy, I. (2016). Production of byproduct uranium and uranium from unconventional resources. Resources, Mining and Transformation to Fuel, 239-251. http://dx.doi.org/10.1016/B978-0-08-100307-7.00009-0

[9] Banu, S.S., Haq, M.N. (2015). Study on the mechanical properties such as compressive strength, split tensile strength and flexural strength for various percentages of phosphogypsum. International Journal of Emerging Trends in Engineering and Development, Report No. 5, 264-387.

[10] Tafu, M., Chohji, T. (2006). Reaction between calcium phosphate and fluoride in phosphogypsum. Journal of the European Ceramic Society, 26(4-5): 767-770. http://dx.doi.org/10.1016/j.jeurceramsoc.2005.06.031

[11] Jordanian Phosphate Mines Company (JPMC), (1998). Annual Report for surveying and studying of water resources in the phosphate mines. Al-Shamil Engineering, Amman, 167.

[12] Chaouqi, N., El Gharous, M., Bouzziri, M. (2017). The improvement of TSP fertilizer production and quality. bioRxiv. Gold Spring Harbor Laboratory. https://doi.org/10.1101/213223

[13] Freyer, D., Voigt, W. (2003). Crystallization and phase stability of $\mathrm{CaSO}_{4}$ and $\mathrm{CaSO}_{4}$-based salts. Monatshefte für Chemie/Chemistry, 134(5): 693-719. https://doi.org/10.1007/s00706-003-0590-3

[14] Sievert, T., Wolter, A., Singh, N.B. (2005). Hydration of anhydrite of gypsum $\left(\mathrm{CaSO}_{4}\right.$.II) in a ball mill. Cement and Concrete Research, 35: 623-630. http://dx.doi.org/10.1016/j.cemconres.2004.02.010
[15] Diop, M.B., Ndiaye, A.A., Ndiaye, S., Lo, B., Sakho, O., Tall, P.D., Beye, A.C., Soboyejo, W. (2005). Phosphogypsum based cement formulation in agreement with standard portland cement in the framework of a concrete code policy for thermal and energetic efficiency of the building. African Concrete Code, Symposium, 306-322.

[16] Buyukkoc, A., Akoz, R., Onat L. (1995). Phosphgypsum as Set Retarder in Portland Cement. IL CEMENTO, 92: 279-286.

[17] Singh, M., Garg, M. (2000). Making of anhydrite cement from waste gypsum. Cement and Concrete Research, 30(4): 571-577. http://dx.doi.org/10.1016/S00088846(00)00209-X

[18] Huang, X., Zhao, X., Bie, S., Yang, C. (2016). Hardening performance of phosphogypsum-slag-based material. Procedia Environmental Sciences, 31: 970-976. http://dx.doi.org/10.1016/j.proenv.2016.03.002

[19] Islam, G.M.S., Chowdhury, F.H., Raihan, M.T., Amit, S.K.S., Islam, M.R. (2017). Effect of phosphogypsum on the properties of portland cement. Procedia Engineering, 171: 744-751. http://dx.doi.org/10.1016/j.proeng.2017.01.440

[20] Pundir, A., Garg, M., Singh, R. (2015). Evaluation of properties of gypsum plaster-superplasticizer blends of improved performance. Journal of Building Engineering, 4: 223-230. http://dx.doi.org/10.1016/j.jobe.2015.09.012

[21] Smadi, M.M., Haddad, R.H., Akour, A.M. (1999). Potential use of phosphogypsum in concrete. Cement and Concrete Research, 29(9): 1419-1425. http://dx.doi.org/10.1016/S0008-8846(99)00107-6

[22] Li, X., Du, J., Gao, L., He, S., Gan, L., Sun, C., Shi, Y. (2017). Immobilization of phosphogypsum for cemented paste backfill and its environmental effect. Journal of Cleaner Production, 156: 137-146. http://dx.doi.org/10.1016/j.jclepro.2017.04.046

[23] Rajkovic, M.B., Toskovic, D.V. (2003). Phosphogypsum surface characterization using scanning electron microscopy. Acta Periodica Technologica, 34: 61-70. http://doi.org/10.2298/APT0334061R

[24] Singh, M. (2002). Treating waste phosphogypsum for cement and plaster manufacture. Cement and Concrete Research, 32(7): 1033-1038. http://dx.doi.org/10.1016/S0008-8846(02)00723-8

[25] Al Attar, L., Al-Oudat, M., Raja, G., Abdul Ghani, B. (2008). Environmental assessment of phosphogypsum stacks. The $9^{\text {th }}$ Arab Conference on the Peaceful Uses of Atomic Energy, Beirut.

[26] US EPA, O. (2006). Radioactive Material from Fertilizer Production. https://www.epa.gov/radtown

[27] Abdelhadi, N.A., Abdelhadi, M.A., El-Hasan, T.M. (2014). The characteristics of cement mortars utilizes the untreated phosphogypsum wastes generated from fertilizer plant, Jordan. Journal of Earth and Environmental Sciences, 6(2): 61-66.

[28] UN-HABITAT. (1994). Building materials and health: Report of the Executive Director: [United Nations Centre for Human Settlements (Habitat)]. Digital Library.

[29] Azabou, S., Mechichi, T., Sayadi, S. (2007). Zinc precipitation by heavy-metal tolerant sulfate-reducing bacteria enriched on phosphogypsum as a sulfate source. Minerals Engineering, 20: 173-178. http://dx.doi.org/10.1016/j.mineng.2006.08.008 
[30] [30] Trifi, H. (2011). Characterization and bioremediation potential of phosphate solubilizing bacteria isolated from Tunisian phosphogypsum, Environmental Sciences, 46(22).

[31] Rice, D.A., Carter, O.C., May, A., Ragin, M.M., Swanton, R.G. (1990). Recovery of sulfur from phosphogypsum: conversion of calcium sulfide to sulfur. Bureau of Mines Report of Investigations, Issue RI 9297.

[32] Rosenwald, R.H., Hamblin, R.J.J., Urban, P., Zimmerman, R.P. (1975). Sulfide oxidation: Sulfox system of pollution control. Product R\&D, 14: 218-226. http://dx.doi.org/10.1021/i360056a002

[33] Akın Altun, İ., Sert, Y. (2004). Utilization of weathered phosphogypsum as set retarder in Portland cement. Cement and Concrete Research, 34(4): 677-680. http://dx.doi.org/10.1016/j.cemconres.2003.10.017

[34] Potgieter, J.H., Potgieter, S.S., McCrindle, R.I., Strydom, C.A. (2003). An investigation into the effect of various chemical and physical treatments of a South African phosphogypsum to render it suitable as a set retarder for cement. Cement and Concrete Research, 33(8): 12231227. http://dx.doi.org/10.1016/S0008-8846(03)00036$\mathrm{X}$

[35] Kacimi, L., Simon-Masseron, A., Ghomari, A., Derriche, Z. (2006). Reduction of clinkerization temperature by using phosphogypsum. Journal of Hazardous Materials, 137(1):
129-137. http://dx.doi.org/10.1016/j.jhazmat.2005.12.053

[36] Singh, M. (2005). Role of phosphogypsum impurities on strength and microstructure of selenite plaster. Construction and Building Materials, 19(6): 480-486. http://dx.doi.org/10.1016/j.conbuildmat.2004.07.010

[37] Tabikh, A.A., Miller, F.M. (1971). The nature of phosphogypsum impurities and their influence on cement hydration. Cement and Concrete Research, 1(6): 663-678. http://dx.doi.org/10.1016/0008-8846(71)90020-2

[38] Sun, Z., Guo, C.Z., Zhou, W.B., Zhu, J.Q. (2010). Influence of phosphogypsum on physical properties and hydration process of Portland cement. World Build Material, 31: 4-7.

[39] Ölmez, H., Yilmaz, V.T. (1988). Infrared study on the refinement of phosphogypsum for cements. Cement and Concrete Research, 18(3): 449-454. https://doi.org/10.1016/0008-8846(88)90079-8

[40] Nurse, R.W. (2007). The effect of phosphate on the constitution and hardening of portland cement. Journal of Applied Chemistry, 2(12): 708-716. http://dx.doi.org/10.1002/jctb.5010021208

[41] El-Didamony, H., Ali, M.M., Awwad, N.S., Fawzy, M.M., Attallah, M.F. (2012). Treatment of phosphogypsum waste using suitable organic extractants. Journal of Radioanalytical and Nuclear Chemistry, 291: 907-914. http://dx.doi.org/10.1007/s10967-011-1547-3 